\title{
Formulation and characterization of tramadol-loaded IPN microgels of alginate and gelatin: Optimization using response surface methodology
}

PRADEEP KUMAR*
INDERBIR SINGH

Chitkara College of Pharmacy Chandigarh-Patiala National Highway Rajpura-140401, Patiala, Punjab, India

Accepted June 7, 2010
Tramadol-loaded interpenetrating polymer network (IPN) alginate-gelatin (AG) microgels (MG) were prepared by the chemical cross-linking technique with glutaraldehyde as cross-linking agent and were optimized using response surfaces. A central composite design for 2 factors, at 3 levels each, was employed to evaluate the effect of critical formulation variables, namely the amount of gelatin $\left(X_{1}\right)$ and glutaraldehyde $\left(X_{2}\right)$, on geometric mean diameter, encapsulation efficiency, diffusion coefficient $(D)$, amount of mucin adsorbed per unit mass $\left(Q_{\mathrm{e}}\right)$ and $50 \%$ drug release time $\left(t_{50}\right)$. Microgels with average particle size in the range of 44.31-102.41 $\mu \mathrm{m}$ were obtained. Drug encapsulation up to $86.5 \%$ was achieved. MGs were characterized by FT-IR spectroscopy to assess formation of the IPN structure and differential scanning calorimetry (DSC) was performed to understand the nature of drug dispersion after encapsulation into IPN microgels. Both equilibrium and dynamic swelling studies were performed in $\mathrm{pH} 7.4$ phosphate buffer. Diffusion coefficients and exponents for water transport were determined using an empirical equation. The mucoadhesive properties of MGs were evaluated in aqueous solution by measuring the mucin adsorbed on MGs. Adsorption isotherms were constructed and fitted with Freundlich and Langmuir equations. In vitro release studies indicated the dependence of drug release on the extent of cross-linking and the amount of gelatin used in preparing IPNs. The release rates were fitted to a power law equation and $\mathrm{Hi}-$ guchi's model to compute the various drug transport parameters, $n$ value ranged from 0.4055 to 0.5754 , suggesting that release may vary from Fickian to quasi-Fickian depending upon variation in the formulation composition.

Keywords: sodium alginate, gelatin, microgels, IPN, diffusion, mucin adsorption

*Correspondence; e-mail: beingprady@gmail.com 
Naturally occurring polymers, being biocompatible and biodegradable, are currently extensively researched by the pharmaceutical industry for the development of novel drug delivery systems. Alginate is a water-soluble, naturally occurring polysaccharide abundantly found in the surface of brown seaweeds (Phaeophyceae, mainly Laminaria). Alginate beads alone or in combination with other polymers have been extensively studied by researchers for their diverse pharmaceutical applications, particularly as drug delivery system (1-3). Moreover, alginate is reported to be non-toxic and biodegradable when given orally and to have a protective effect on the mucous membrane of the upper respiratory tract $(4)$.

Gelatin is a fibrous protein produced by partial hydrolysis of colagen extracted from the bones, connective tissues, organs, and some intestines of animals such as domesticated cattle and horses. Gelatin in conjunction with alginate (after cross-linking) may be potentially used for controlling the release of drugs, insecticides, pheromones $(5,6)$. In the current study, gelatin is being incorporated in Na-alginate IPN microgels with the aim to improve the mucoadhesive strength and gel stability of alginate. An interpenetrating polymer network (IPN) is any material containing two polymers, each in network form. The advantages of IPN systems are enhancement of the mechanical strength of the network and increase in the compatibility of polymer blends, which exhibit favorable properties of phase separated materials (7).

Tramadol hydrochloride is a centrally acting analgesic. The chemical name of tramadol hydrochloride is $( \pm$ ) cis-2-[(dimethylamino) methyl]-1-(3-methoxyphenyl) cyclohexanol hydrochloride. Tramadol is marketed as a mixture and the $(+)$ - is approximately four times more potent than the (-)-enantiomer in terms of $\mu$-opioid receptor affinity and 5-HT reuptake, whereas the (-)-enantiomer is responsible for noradrenaline reuptake effects (8).

The present study aims to prepare drug-loaded sodium alginate-gelatin IPN microgels by the chemical cross-linking method and to study the effect of gelatin and cross-linking agent on release characteristics of the drug. The formulated microgels were analyzed for particle size, encapsulation efficiency, diffusion coefficient, amount of mucin adsorbed per unit mass and in-vitro release. Various exponents of swelling, adsorption and release studies were calculated. Response surface methodology (RSM) is a widely practiced approach in the development and optimization of drug delivery devices. Design of experiments generates polynomial equations and mapping of the response over the experimental domain to determine the optimum formulation(s) (9).

\section{EXPERIMENTAL}

\section{Materials}

Tramadol hydrocloride was received as a gift sample from Indswift Laboratories Ltd., India and gelatin from Cadila Healthcare Ltd., India. Mucin from porcine stomach type III (bound sialic acid 0.5-1.5 \%) was procured from Sigma Aldrich, USA. Sodium alginate and glutaraldehyde were procured from Loba Chemie, India. All the reagents were of analytical grade and were used as received. 
P. Kumar and I. Singh: Formulation and characterization of tramadol-loaded IPN microgels of alginate and gelatin: Optimization using response surface methodology, Acta Pharm. 60 (2010) 295-310.

\section{Formulation of sodium alginate-gelatin IPN microgels}

Chemical cross-linking technique was used to formulate sodium alginate-gelatin IPN microgels. Alginate-gelatin solution was prepared in distilled water by gentle heating. A weighed amount of drug was added to the prepared solution and mixed homogeneously using a magnetic stirrer. The polymer solution containing the drug was preheated to $40^{\circ} \mathrm{C}$ and then added dropwise, using a syringe fitted with a $24 \mathrm{G}$ needle, into olive oil (containing a lipophilic surfactant Span 80, $1 \%, V / V$ ) at a temperature of $40{ }^{\circ} \mathrm{C}$ under stirring using a mixer with a marine impeller. A $15-\mathrm{mL}$ volume of acetone was then added and the mixture was further stirred for $30 \mathrm{~min}$. The microgels were then cross-linked with glutaraldehyde solution in acetone/ $0.01 \mathrm{~mol} \mathrm{~L}^{-1} \mathrm{HCl}$ solution (7:3) for a predetermined time. The mixture was then centrifuged at a speed of $5000 \mathrm{rpm}$ for 5 min and the microgels were recovered. The resulting microgels were thereafter washed with acetone and dried at $28^{\circ} \mathrm{C}$.

\section{Experimental design}

A Central Composite Design with $\alpha=1$ was employed as per the standard protocol (10). The amount of gelatin $\left(X_{1}\right)$ and the amount of glutaraldehyde $\left(X_{2}\right)$ were selected as the factors whose effect will be studied on the response variables. Table I summarizes the 13 experimental runs studied, their factor combinations, and the translation of the coded levels to the experimental units employed during the study. Particle size, encapsulation efficiency $(E E)$, diffusion coefficient $(D)$, amount of mucin adsorbed per unit mass $\left(Q_{e}\right)$ and the time taken to release $50 \%$ of the drug $\left(t_{50}\right)$ were taken as response variables.

\section{Particle size and morphological studies}

The particle size of the prepared drug loaded MGs (after drying) was measured using an optical microscope. The mean of $100 \mathrm{MGs}$ was noted as particle size. All the readings were the average of three trials \pm SD. The shape and surface of microgels was examined by scanning electron microscopy (268D, Fei- Philips, USA).

\section{Drug encapsulation efficiency}

The MGs were evaluated for tramadol content by incubating $50 \mathrm{mg}$ of microgels with $5 \mathrm{~mL}$ of water for complete swelling. The swollen MGs were crushed in an agate mortar with a pestle, and the homogeneous solution thus formed was sonicated for 5 min at $60 \mathrm{MHz}$. Tramadol was analyzed by a UV spectrophotometer (Systronics 2202, India) at $272 \mathrm{~nm}$. Experiments were performed in triplicate and average values were considered for data treatment and calculations. 
P. Kumar and I. Singh: Formulation and characterization of tramadol-loaded IPN microgels of alginate and gelatin: Optimization using response surface methodology, Acta Pharm. 60 (2010) 295-310.

\section{Diffusion coefficient}

To determine the nature of water diffusion into the IPN hydrogels, initial swelling data were fitted to the following exponential equation (11).

$$
F=M_{t} / M_{\infty}=k t^{n}
$$

where $F$ denotes the amount of water fraction at time $t, M_{\mathrm{t}}$ and $M_{\infty}$ represent the amount of water absorbed by the MGs at time $t$ and at equilibrium, $k$ is a characteristic constant of the hydrogel, and $n$ is a characteristic exponent of the mode of transport of the penetrate.

To calculate the diffusion coefficient of water moving through the IPN MGs, the following equation was employed (11):

$$
D=\pi r^{2}(k / 4)^{1 / n}
$$

where, $D$ is the diffusion coefficient of water $\left(\mathrm{cm}^{2} \mathrm{~s}^{-1}\right)$ and $r$ is the radius of dry gel.

\section{Amount of mucin adsorbed $\left(\mathrm{Q}_{e}\right)$}

Adsorption studies were carried out using the mucous glycoprotein assay method (12), where a periodic acid/Schiff (PAS) colorimetric method was used to determine the free mucin concentration in order to assess the amount of mucin adsorbed on the alginate-gelatin MGs and its effect on the assessment of mucoadhesive behavior of IPN microgels.

\section{In vitro drug release}

In vitro release of tramadol from the MGs was performed in USP XXIII apparatus I $\left(37 \pm 0.5^{\circ} \mathrm{C}, 50 \mathrm{rpm}\right)$ using $0.1 \mathrm{~mol} \mathrm{~L}^{-1} \mathrm{HCl}(\mathrm{pH} 1.2,500 \mathrm{~mL})$ as dissolution medium for the first $2 \mathrm{~h}$ and subsequently the rest of the release study was performed in phosphate buffer ( $\mathrm{pH} 7.4,500 \mathrm{~mL}$ ) for the following $12 \mathrm{~h}$ (13). A quantity of drug loaded microgels equivalent to $100 \mathrm{mg}$ of the drug for each batch was employed in all dissolution studies. The aliquots, following suitable dilution, were analyzed spectrophotometrically at $272 \mathrm{~nm}$.

The power law equation and Higuchi's model were fitted to the kinetic data of drug release. Power law model can be expressed as $f_{\mathrm{t}}=M_{\mathrm{t}} / M_{\infty}=k_{\mathrm{p}} t^{n}(14)$. According to Higuchi's model, the fraction of the drug released is plotted vs. the square root of time $f_{\mathrm{t}}=M_{\mathrm{t}} / M_{\infty}=k_{\mathrm{H}} t^{1 / 2}(15)$. In case of release studies, $M_{\mathrm{t}}$ corresponds to the amount of drug released in time $t, M_{\infty}$ is the total amount of drug released after an infinite time, $k$ is a constant related to the structural and geometric properties of the drug release system and $n$ is the diffusional exponent.

\section{Optimization data analysis and numerical optimization}

Various RSM computations for the current optimization study were performed employing the Design-Expert software (Version 7.1.4, Stat-Ease Inc, USA). Polynomial mo- 
P. Kumar and I. Singh: Formulation and characterization of tramadol-loaded IPN microgels of alginate and gelatin: Optimization using response surface methodology, Acta Pharm. 60 (2010) 295-310.

dels including interaction and quadratic terms were generated for all the response variables using the multiple linear regression analysis approach as represented in Eq. (1):

$$
Y=\beta_{0}+\beta_{1} X_{1}+\beta_{2} X_{2}+\beta_{3} X_{1} X_{2}+\beta_{4} X_{1}^{2}+\beta_{5} X_{2}^{2}+\beta_{6} X_{1} X_{2}^{2}+\beta_{7} X_{1}^{2} X_{2}
$$

where, $\beta_{0}$ is the intercept representing the arithmetic average of all quantitative outcomes of 13 runs, $\beta_{1}$ to $\beta_{7}$ are the coefficients computed from the observed experimental values, $Y, X_{1}$ and $X_{2}$ are the coded levels of the independent variable(s). Numerical optimization using the desirability approach was employed to locate the optimal settings of the formulation variables to obtain the desired response.

\section{Fourier transform infrared (FTIR) spectra}

FTIR spectra were recorded on a Shimadzu 8400 infra-red spectrophotometer (Japan), using $\mathrm{KBr}$, to confirm the formation of the IPN structure and also to find the chemical stability of the drug in the formulation. FTIR spectra of the polymer mixture, drug-loaded microgels and plain tramadol were recorded in the range of $4000-400 \mathrm{~cm}^{-1}$.

\section{Differential scanning calorimetry (DSC)}

DSC study of pure tramadol, placebo microgels and drug loaded microgels was conducted using a Model Q 10 (TA Systems, USA) thermal analyzer at a scanning rate of $10{ }^{\circ} \mathrm{C} \mathrm{min}-1$ in the temperature range of 15 to $350{ }^{\circ} \mathrm{C}$ under a nitrogen atmosphere (flow rate $20 \mathrm{~mL} \mathrm{~min}^{-1}$ ).

The IPN microgels of sodium alginate and gelatine were prepared by the simple emulsification phase separation technique. The SEM images show that the drug loaded microspheres cross-linked with glutaraldehyde are spherical with a smooth surface as shown in Fig. 1.

\section{RESULTS AND DISCUSSION}

\section{FTIR}

The characteristic peak of sodium alginate appearing at $819 \mathrm{~cm}^{-1}$ was not observed in the spectra of microgels (Fig. 2). The absorption peak at $1624 \mathrm{~cm}^{-1}$ assigned to the asymmetrical stretching vibration of $-\mathrm{COO}^{-}$groups of sodium alginate coupled with the peaks at 1652 and $1558 \mathrm{~cm}^{-1}$ of gelatin shifted to $1634 \mathrm{~cm}^{-1}$ in placebo microgels suggesting that new hydrogen bonds were formed between $-\mathrm{COO}^{-}$groups of sodium alginate and $-\mathrm{CONH}_{2}$ groups of gelatin. Furthermore, the band of gelatin centered at about 3400 $\mathrm{cm}^{-1}$, which was the stretching vibration or $-\mathrm{NH}_{2}$ groups involved in both inter- and intra-molecular hydrogen bonds (the band has a less intense component at $3400 \mathrm{~cm}^{-1}$ showing that there may be more than one type of feasible intermolecular hydrogen bonds), broadened and coupled with $-\mathrm{OH}$ band of sodium alginate at $3450 \mathrm{~cm}^{-1}$, included by the addition of sodium alginate to gelatin, implied the occurrence of hydrogen bonds between $-\mathrm{OH}$ groups of sodium alginate and $-\mathrm{NH}_{2}$ groups of gelatin molecules. FTIR spectra of pure drug and drug loaded microgels revealed the principle peaks at 1361 


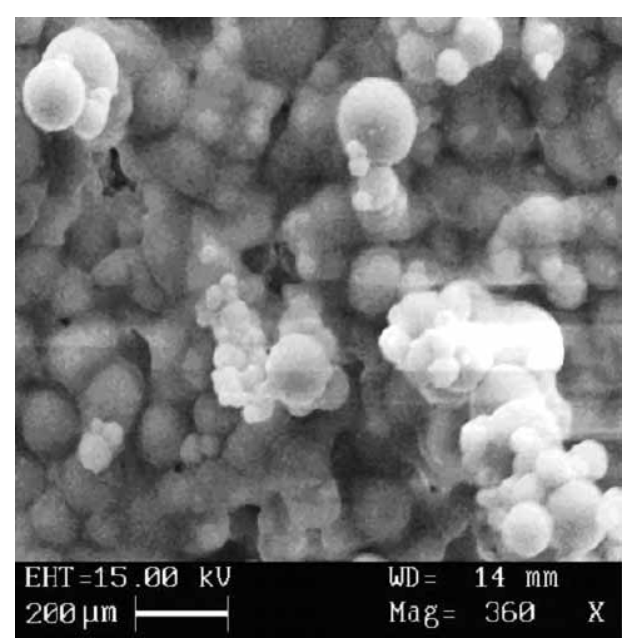

Fig. 1. Scanning electron photomicrographs of AG IPN microgels (X 500).

$\mathrm{cm}^{-1}$ and $3312 \mathrm{~cm}^{-1}$ corresponding to the amine stretch and $-\mathrm{OH}$ stretch, respectively. The IR spectrum of microgels of tramadol also presented the peaks characteristics of pristine drug, indicating no interaction between the drug and the polymer matrix.

\section{DSC}

DSC thermograms of placebo microgels, drug-loaded microgels and pure tramadol are displayed in Fig. 3. Placebo microgels, drug-loaded microgels and pure tramadol exhibited principal peaks at 79.37 and 215.45 ${ }^{\circ} \mathrm{C}, 79.90$ and $216.32{ }^{\circ} \mathrm{C}$ and 183.84 and $269.77{ }^{\circ} \mathrm{C}$, respectively. The thermograms of IPN microgels containing tramadol are almost identical to those of the placebo IPN microgels $\left(79.90 \sim 79.37^{\circ} \mathrm{C}\right.$ and 216.32 $\sim 215.45{ }^{\circ} \mathrm{C}$, respectively). Also, the sharp peak at $183.84{ }^{\circ} \mathrm{C}$ corresponding to tramadol was absent in the drug loaded microgels, indicating probable formation of a drug-polymer inclusion complex, ensuing the shielding of the characteristic peaks of tramadol. This inclusion complex might be a factor affecting the release of the drug from the cross-linked microgels.

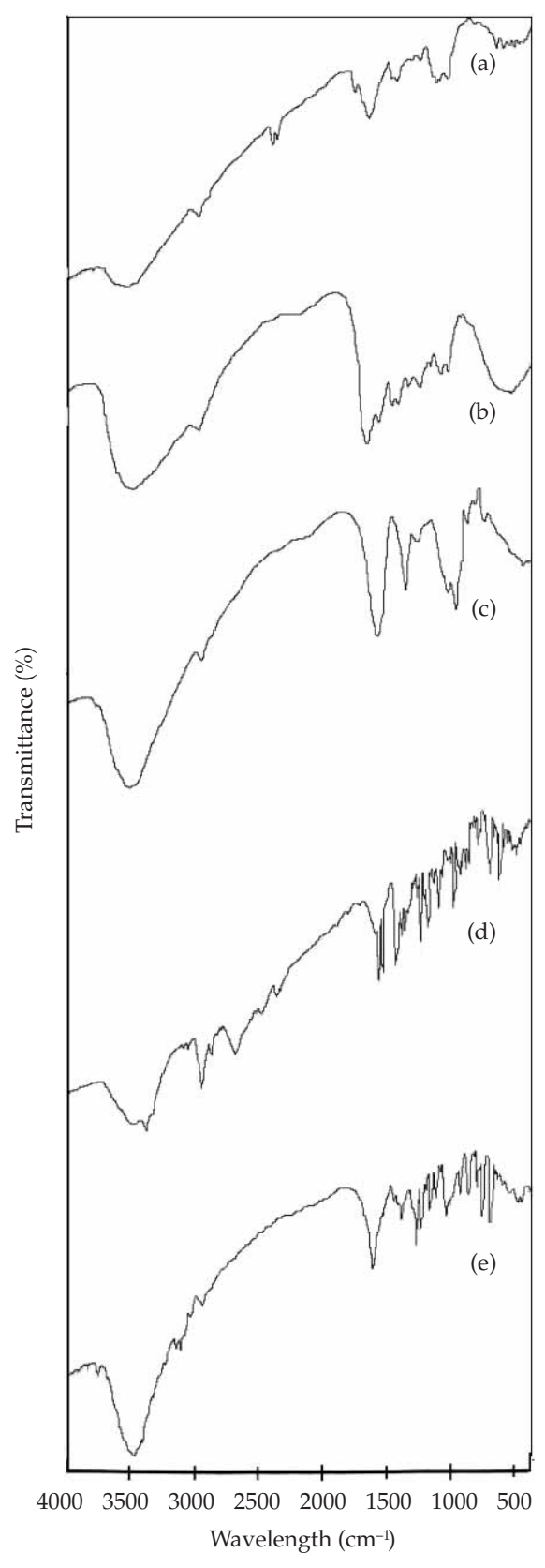

Fig. 2. FTIR spectra of: a) gelatin, b) sodium alginate and c) placebo microgels. 
P. Kumar and I. Singh: Formulation and characterization of tramadol-loaded IPN microgels of alginate and gelatin: Optimization using response surface methodology, Acta Pharm. 60 (2010) 295-310.

\section{Mathematical modeling}

Mathematical relationships generated using multiple linear regression analysis for the studied response variables are expressed in Eqs. (2) - (6) in terms of coded factors:

$$
\begin{gathered}
\text { particle size }=81.26-13.14 X_{1}-14.07 X_{2}+1.88 X_{1} X_{2}-6.27 X_{1}^{2}-2.26 X_{2}^{2} \\
\text { encapsulation efficiency }=75.12+4.45 X_{1}+4.21 X_{2}-0.58 X_{1} X_{2}+2.61 X_{1}^{2}+0.17 X_{2}^{2} \\
\text { diffusion coefficient }=0.22-0.15 X_{1}-0.11 X_{2}+0.87 X_{1} X_{2}+0.66 X_{1}^{2}+0.039 X_{2}^{2}- \\
\quad-0.035 X_{1} X_{2}^{2}-0.043 X_{1}^{2} X_{2} \\
Q_{e}=12.29+1.27 X_{1}-0.24 X_{2}-0.58 X_{1} X_{2}-3.37 X_{1}^{2}+0.69 X_{2}^{2}-3.92 X_{1} X_{2}^{2} \\
t_{50}=118.57+32.73 X_{1}+18.83 X_{2}+5.53 X_{1} X_{2}+9.38 X_{1}^{2}+2.16 X_{2}^{2}
\end{gathered}
$$

The values obtained for the main effects of each factor in Eqs. (2), (3) and (4) reveal that the amounts of gelatin $\left(X_{1}\right)$ and glutaraldehyde $\left(X_{2}\right)$ have a comparable effect on the values of particle size, encapsulation efficiency and diffusion coefficient, whereas Eqs. (5) and (6) reveal that the amount of gelatin $\left(X_{1}\right)$ has a more influential role for the response variables $Q_{\mathrm{e}}$ and $t_{50}$.

\section{Particle size}

The response surface plot in Fig. 4a reveals that particle size varies in linear fashion with the increase in the amount of each factor. Particle size decreases with an increase in concentration of both $X_{1}$ and $X_{2}$ (Table I), which could be attributed to shrinkage of microgels caused by the high degree of cross-linking resulting in the formation of more rigid network structures (16). Also, by increasing the amount of gelatin in the formulation, a decrease in the size of microgels was observed, which may be attributed to the formation of smaller droplets due to the increase in the viscosity of solution with increasing concentration of gelatin during emulsification.

\section{Encapsulation efficiency}

The predictor equation generated [Eq. (3)] revealed that the levels of both $X_{1}$ and $X_{2}$ had a considerable positive effect on the encapsulation efficiency. The response surface plot (Fig. 4b) illustrates that the encapsulation increased from 68.4 to $78.4 \%$ and from 78.8 to $86.5 \%$ at low and high levels of glutaraldehyde, respectively, as the gelatin amount increased. It was evident from the 3-D plots that the encapsulation efficiency enhanced from 68.4 to $78.8 \%$ and from 78.4 to $86.5 \%$ at high and low levels of $X_{1}$, respectively, as the glutaraldehyde amount increased (Table I). This is due to the formation of a rigid network that restricted leaching of the drug molecules during microgel preparation and hence caused retention of more drug molecules. 
P. Kumar and I. Singh: Formulation and characterization of tramadol-loaded IPN microgels of alginate and gelatin: Optimization using response surface methodology, Acta Pharm. 60 (2010) 295-310.

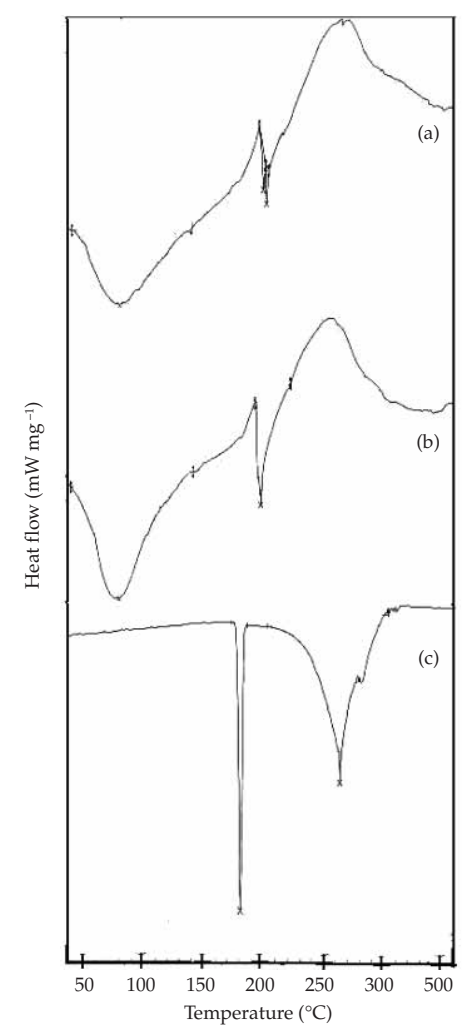

Fig. 3. DSC of: a) drug-loaded microgels, b) placebo microgels and c) tramadol.

amount of gelatin in the formulation.

\section{Dynamic swelling kinetics}

The swelling behaviour of MGs is linked to the diffusion process, which in turn depends on the nature of polymer network, cross-linking density and elasticity of the polymeric network (17). The negative influence of gelatin on the diffusion coefficient is clearly demonstrated by the response surface plots (Fig. 4c). All batches showed good swelling initially (6-8 h), but marked variation in swelling was observed in all the batches after $24 \mathrm{~h}$. Batches III, VI and IX showed perfect swelling with no deformation in the swelled matrices. The swelling kinetic curves of the MGs are given in Fig. 5. The data in this figure show that both the swelling ratio and the swelling rate decreased with increasing the amount of the crosslinker. The swelling ratio of the MGs reduced due to a dense and stiffer three-dimensional structure formed at high glutaraldehyde concentration, which might have prohibited the transport of water molecules. However, the swelling capacity of MGs decreased with increasing the amount of gelatin in the matrix, which may be due to the formation of a rigid IPN structure as a result of increased entanglement of both polymeric chains, as evident from the $\mathrm{D}$ values presented in Table I. Diffusion coefficient falls in the range from 0.07 to $0.74 \times 10^{-6} \mathrm{~cm}^{2} \mathrm{~s}^{-1}$ and decreases systematically with increasing amount of the cross-linking agent as well as with increasing

\section{Amount of mucin adsorbed $\left(\mathrm{Q}_{e}\right)$}

The amount of mucin adsorbed was found to be increasing with an increase in mucin concentration. The quadratic model generated [Eq. (5)] revealed that the levels of gelatin and glutaraldehyde had a significant antagonistic influence on $Q_{\mathrm{e}}$ without producing any interaction. $X_{1}$ was found to have a positive influence on the encapsulation efficiency since it showed an increase with an increase in the level of gelatin. Further, the amount of mucin adsorbed decreased with an increase in the amount of glutaraldehyde, as evident from the response surface plots (Fig. 4d). In the case of batches I, II and III, the amount of mucin adsorbed increased from 11.6 to $15.6 \mathrm{mg} \mathrm{g}^{-1}$, with an increase in gelatin amount from 50 to $100 \mathrm{mg}$, which may be due to increasing availability of cations in the matrix to interact with the negatively charged mucin. Further, in the case of batches IV to VI and VII to IX, a "region of maximum" (12.2 and $13.6 \mathrm{mg} \mathrm{g}^{-1}$ for batches 
$\mathrm{V}$ and VIII, respectively) for the amount of mucin adsorbed was observed at the intermediate level of gelatin, as shown in the response surface. The lower value of $Q_{\mathrm{e}}$ for batches VI and IX may be attributed to the denser matrix owing to high cross-linking density. Also, the presence of higher amounts of both gelatin and glutaraldehyde may result in low swelling and low surface exposure. The polyampholytic structure of IPNs may have an additional effect on tissue adhesion, due to the formation of transitional physical crosslinks between cationic and anionic groups carried by network chains (18). Besides, with a large amount of strong hydrogen-bonding groups $\left(-\mathrm{OH},-\mathrm{COOH},-\mathrm{NH}_{2}\right)$ on polymer chains, IPNs could adhere to the mucus layer through hydrogen bridges (19). Thus, these studies indicate that there may be an increase in the residence time of the formulation in the gastrointestinal tract by optimizing the amounts of $X_{1}$ and $X_{2}$ in the microgels.

\section{Adsorption isotherms}

The data obtained were interpreted using Freundlich [Eq. (7)] or Langmuir [Eq. (8)] equations describing the adsorption isotherms:

$$
\begin{gathered}
C_{\mathrm{ads}}=K C_{\mathrm{e}^{n}} \\
C_{\mathrm{ads}}=a C_{\mathrm{e}}\left(b+C_{\mathrm{e}}\right)
\end{gathered}
$$

where $C_{\text {ads }}$ is the concentration of mucin adsorbed at equilibrium and $C_{\mathrm{e}}$ is the concentration of free mucin at equilibrium. Values of different constants were obtained from the graphs of the above equations. For the Langmuir equation, $1 / C_{\text {ads }}$ was plotted against $1 / C_{\mathrm{e}}$ to get the constants and for the Freundlich equation, $\log C_{\text {ads }}$ was plotted against $\log C_{\mathrm{e}}$ to get the constants (12).

The equilibrium free concentration of mucin in solution was determined for the measurement of mucin adsorption on MGs and the data so obtained were fitted with Freundlich and Langmuir equations. Straight lines were obtained, and the constants from these lines are listed in Table II. It was observed that $R^{2}$ was significantly higher for the Langmuir equation compared to the Freundlich equation in case of batches I to III. This may be due to a more specific adsorption process where electrostatic interaction is involved. However, in batches IV to XI, the $R^{2}$ values vary on either side. The adsorption of mucin to MGs is expected to be dominated by the electrostatic attraction between the positively charged gelatin and negatively charged mucin as the amount of mucin adsorbed increased with increasing mucin concentration.

\section{In vitro drug release}

Drug release from the IPN microgels was characterized by an initial phase of high drug release (burst effect) resulting in the biphasic release pattern, which may be due to peripheral attachment of the drug as a result of expulsion during microgel drying or drug migration as a result of solvent drag during drying. The second-order polynomial model generated in Eq. (6) revealed that gelatin levels have a positive and more pro- 
P. Kumar and I. Singh: Formulation and characterization of tramadol-loaded IPN microgels of alginate and gelatin: Optimization using response surface methodology, Acta Pharm. 60 (2010) 295-310.
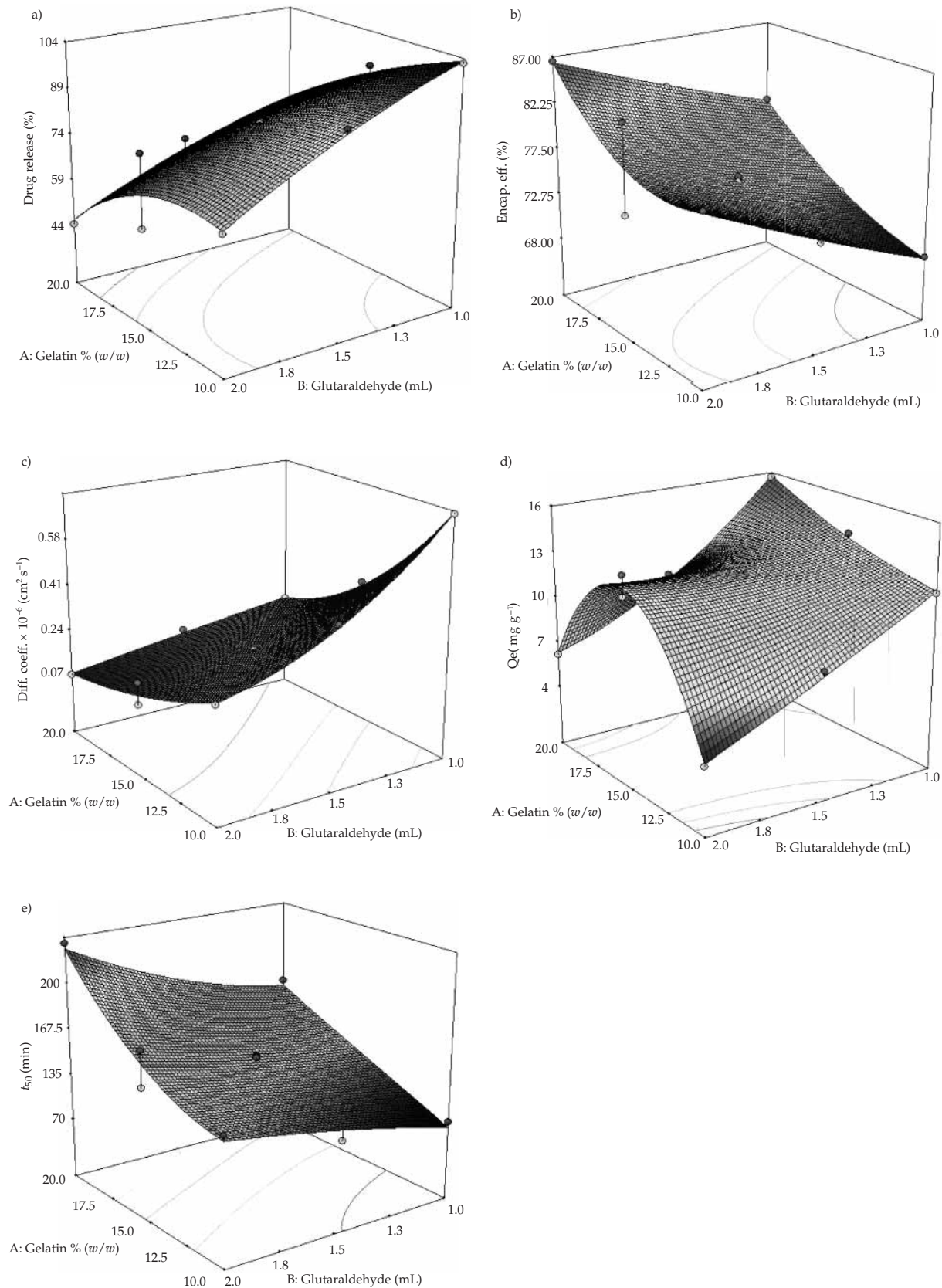

Fig. 4. Response surface plot showing the influence of amount of gelatin $\left(\mathrm{X}_{1}\right)$ and glutaraldehyde $\left(\mathrm{X}_{2}\right)$ on: a) particle size, b) encapsulation efficiency, c) diffusion coefficient, d) amount of mucin adsorbed, e) $t_{50}$. 
nounced influence on $t_{50}$, since it improved on incorporation of higher amounts of gelatin. The response surface plots (Fig. 4e) illustrate that $t_{50}$ increased from 82.6 to $115.9 \mathrm{~min}$ and from 140.7 to $196.1 \mathrm{~min}$ at low and high levels of gelatin, respectively, as the glutaraldehyde amount increased. Also, $t_{50}$ increased from 82.6 to $140.7 \mathrm{~min}$ and from 115.9 to $196.1 \mathrm{~min}$ at low and high levels of glutaraldehyde, respectively, as the amount of gelatin increased (Table I). Drug release rates are higher for microgels having a lower amount of gelatin compared to those having a higher amount of gelatin. This further explains the formation of stiffer polymeric chain entanglements at higher amounts of gelatin in the IPN, thus reducing the rate of swelling as well as drug release. It was observed that release rates depend upon the amount of GA used during cross-linking (Fig. 6.) Release was slower for formulations in which higher amount of glutaraldehyde was used compared to those formulations in which lower amount of glutaraldehyde was present in the matrix. This could be due to the fact that at higher cross-linking, the free volume of the matrix will decrease, thereby hindering the transport of drug molecules through the matrix. This could also reduce the rate of swelling as well as the rate of drug release from the matrix. The release rate can be correlated with the diffusion coefficient (Table I), which indicates that as the diffusion coefficient increases, the release rate also increases.

Release results were also analyzed using the empirical equation to estimate the release kinetic parameter, $k\left(\mathrm{~min}^{-n}\right)$ and the diffusional exponent, $n$ (14). By applying the least-squares estimation method to the release data at $95 \%$ confidence level, the values of $k$ and $n$ were determined. This data along with the values of correlation coefficient, $R$, is presented in Table II.

Values of $k$ decrease with increasing cross-link density (decreases from 8.63 to 8.03 and $4.77 \mathrm{~min}^{-1 / 3}$ in case of formulations I, IV and VII, respectively) as well as with increasing amount of gelatin (decreases from 8.63 to 6.52 and $3.86 \mathrm{~min}^{-1 / 3}$ in case of formulations I, II and III, respectively) in the IPN matrix. The decrease in kinetic constant values reflects the decrease in the rate of drug release, which might be due to the dominance of chain entanglement and subsequently low dissolution of polymer (as the amount of glutaraldehyde is increased) and due to increasing viscosity of polymeric mixtures (as the amount of gelatine is increased). On the other hand, values of $n$ increased with in-

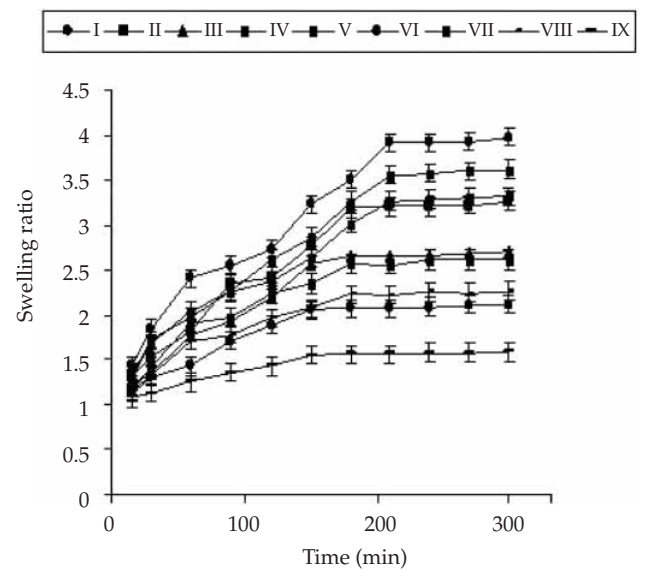

Fig. 5. Swelling kinetics of various formulation batches of AG-IPN microrogels. Error bars represent the standard deviation $(n=3)$. 
P. Kumar and I. Singh: Formulation and characterization of tramadol-loaded IPN microgels of alginate and gelatin: Optimization using response surface methodology, Acta Pharm. 60 (2010) 295-310.

creasing cross-link density as well as with increasing amount of the gelatin in the IPN matrix. It was observed that when the polymer concentration was increased, the drug release rate decreased. This may be due to the large degree of swelling because of higher polymer concentration. This is in accord with the solvent diffusion studies. The value of $n$ ranged from 0.4055 to 0.5754 , suggesting that the drug release mechanism can vary from Fickian to quasi-Fickian, which indicates that the drug release occurred through diffusion in the hydrated matrix and polymer relaxation, depending upon variation in the composition of the formulation. The slight deviation from the Fickian diffusion may be due to the small amount of viscoelastic relaxation of the matrix during water penetration. The values of $R^{2}$ for the different batches suggest that the release followed Higuchi kinetics and hence was diffusion controlled. The IPN material synthesized in the present research was found to form a potential hydrogel, which can find applications in the controlled release of tramadol. The material has a good controlled release behavior and was found to hold the encapsulated drug for a longer period of time (longer drug retaining capacity).

\section{Numerical optimization}

A numerical optimization technique using the desirability approach was employed to develop a new formulation with the desired responses. Upon comprehensive evaluation of the feasibility search and subsequently exhaustive grid searches, the formulation composition with gelatin concentration of 17.9 and the amount of glutaraldehyde $1.3 \mathrm{~mL}$, fulfilled maximum requirements of an optimum formulation because of better regulation of the release rate and higher mucin adsorption. The optimized formulation was

Table II. Estimated values of various exponents under adsorption and release studies

\begin{tabular}{|c|c|c|c|c|c|c|c|c|c|c|c|}
\hline \multirow{3}{*}{ Code } & \multicolumn{6}{|c|}{ Adsorption isotherms } & \multicolumn{5}{|c|}{ Release kinetics } \\
\hline & \multicolumn{3}{|c|}{ Langmuir $^{\mathrm{a}}$} & \multicolumn{3}{|c|}{ Freundlich ${ }^{\mathrm{b}}$} & \multicolumn{2}{|c|}{ Higuchic $^{\mathrm{c}}$} & \multicolumn{3}{|c|}{ Power law ${ }^{\mathrm{d}}$} \\
\hline & a & $\mathrm{b}$ & $R^{2}$ & $\begin{array}{c}K \\
\left(\mathrm{mg} \mathrm{g}^{-1}\right)\end{array}$ & $n$ & $R^{2}$ & $\begin{array}{c}k_{\mathrm{H}} \\
\left(\mathrm{min}^{-1 / 2}\right)\end{array}$ & $R^{2}$ & $n$ & $\begin{array}{c}k_{\mathrm{P}} \\
\left(\mathrm{min}^{-1 / 3}\right)\end{array}$ & $R^{2}$ \\
\hline I & -0.113 & 0.153 & 0.818 & 172.62 & 1.644 & 0.781 & 3.941 & 0.985 & 0.4055 & 8.63 & 0.978 \\
\hline II & -0.029 & 0.012 & 0.947 & 93.626 & 1.074 & 0.942 & 4.041 & 0.991 & 0.4514 & 6.52 & 0.991 \\
\hline III & -0.021 & 0.009 & 0.941 & 94.156 & 1.143 & 0.928 & 3.881 & 0.989 & 0.5257 & 3.86 & 0.957 \\
\hline IV & -0.103 & 0.027 & 0.956 & 103.56 & 0.839 & 0.972 & 3.909 & 0.991 & 0.4138 & 8.03 & 0.988 \\
\hline $\mathrm{V}$ & -0.039 & 0.014 & 0.945 & 93.907 & 1.028 & 0.949 & 3.848 & 0.991 & 0.4503 & 5.93 & 0.973 \\
\hline VI & -0.061 & 0.019 & 0.954 & 92.982 & 0.932 & 0.965 & 3.890 & 0.987 & 0.5725 & 3.02 & 0.953 \\
\hline VII & -0.049 & 0.016 & 0.976 & 151.04 & 0.587 & 0.972 & 4.217 & 0.994 & 0.5016 & 4.77 & 0.982 \\
\hline VIII & -0.110 & 0.027 & 0.963 & 111.60 & 0.832 & 0.925 & 3.728 & 0.989 & 0.5264 & 3.93 & 0.977 \\
\hline IX & -0.241 & 0.057 & 0.948 & 119.64 & 0.713 & 0.977 & 3.668 & 0.994 & 0.5754 & 2.46 & 0.973 \\
\hline
\end{tabular}




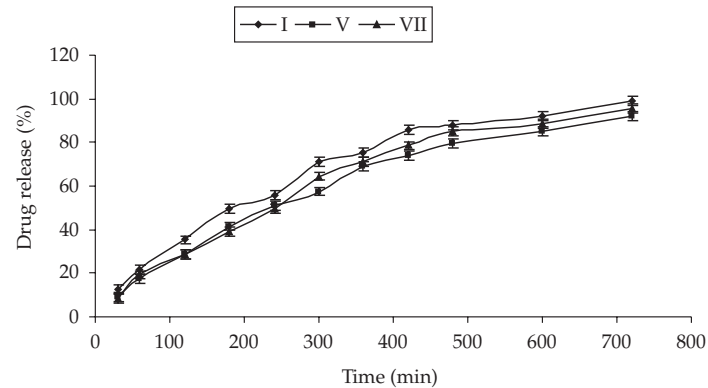

Fig. 6. In vitro release profile of formulations depicting the effect of polymer ratio. Error bars represent the standard deviation $(n=3)$.

evaluated for various dependent variables. The response values were calculated and compared to the corresponding predicted values. Table III lists the values of the observed responses and those predicted by mathematical models along with the percentage prediction errors. The prediction error for the response parameters ranged between 3.1 and $3.6 \%$ with the value of absolute error of $3.3 \pm 0.8 \%$. Drug release from the optimized formulation was found to follow Fickian diffusion and was characterized by the Higuchi kinetic model.

\section{CONCLUSIONS}

An IPN structure was prepared by chemically cross-linking sodium alginate with gelatin using glutaraldehyde. FTIR spectroscopy and DSC confirmed the formation of the IPN structure and probable formation of a drug-polymer inclusion complex, respectively. The dependent variables viz. geometric mean diameter, encapsulation efficiency, diffusion coefficient, amount of mucin adsorbed per unit mass and drug release could be modulated by varying the critical formulation variables, namely, the amounts of gelatin and glutaraldehyde. Mucin adsorption capacity of microgels was determined and adsorption isotherms of the system were fitted in Langmuir and Freundlich equations. High degree of prognosis obtained using the response surface methodology corrobo-

Table III. Comparison of experimentally observed responses of the optimized microgel formulation with predicted responses

\begin{tabular}{lcccc}
\hline Response parameters & $\begin{array}{c}\text { Constraints } \\
\text { set }\end{array}$ & $\begin{array}{c}\text { Observed } \\
\text { values }^{\mathbf{a}}\end{array}$ & $\begin{array}{c}\text { Predicted } \\
\text { value }\end{array}$ & Error (\%) \\
\hline Particles size $(\mu \mathrm{m})$ & $50-100 \mu \mathrm{m}$ & $\begin{array}{c}71.32 \pm 1.38 \\
\text { (optical) }\end{array}$ & 73.61 & 3.1 \\
Encapsulation efficiency $(\%)$ & Maximize & $79.96 \pm 2.06$ & 77.38 & 3.2 \\
Diffusion coefficient $\times 10^{6}\left(\mathrm{~cm}^{2} \mathrm{~s}^{-1}\right)$ & Minimize & $0.139 \pm 0.002$ & 0.134 & 3.6 \\
$Q_{\mathrm{e}}\left(\mathrm{mg} \mathrm{g}^{-1}\right)$ & Maximize & $12.85 \pm 0.08$ & 13.27 & 3.2 \\
$t_{50}(\mathrm{~min})$ & Maximize & $177.21 \pm 26.15$ & 183.90 & 3.6 \\
& Absolute error $3.3 \pm 0.8 \%$ & & \\
\hline
\end{tabular}

a Values are mean $\pm \mathrm{SD}(n=3)$. 
P. Kumar and I. Singh: Formulation and characterization of tramadol-loaded IPN microgels of alginate and gelatin: Optimization using response surface methodology, Acta Pharm. 60 (2010) 295-310.

rates that a 2-factor central composite design is quite efficient in optimizing drug delivery systems that exhibit nonlinearity in response(s). Incorporation of gelatin along with alginate in the IPN structure was found to enhance mucin adsorption and significantly reduce gel erosion, which makes the AG-IPN-MGs suitable candidates for the controlled release mucoadhesive drug delivery system of tramadol.

Acknowledgements. - The authors are grateful to Dr. Madhu Chitkara, Director, Chitkara Institute of Engineering and Technology, Rajpura, Patiala, India, Dr. Ashok Chitkara, Chairman, Chitkara Educational Trust, Chandigarh, India, and Dr. Sandeep Arora, Director, Chitkara College of Pharmacy, Rajpura, Patiala, India for support and institutional facilities.

\section{REFERENCES}

1. M. K. Das and P. C. Senapati, Furosemide-loaded alginate microspheres prepared by chemical cross-linking technique: Morphology and release characteristics, Indian J. Pharm. Sci. 70 (2008) 77-84; DOI: 10.4103/0250-474X.40336.

2. V. U. Rao, M. Vasudha, K. Bindu, S. Samanta, P. S. Rajinikanth, B. Mishra and J. Balasubramaniam, Formulation and in vitro characterization of sodium alginate-gellan beads of glipizide, Acta Pharm. Sci. 49 (2007) 13-28.

3. Y. J. Kim, H. G. Park, Y. L. Yang, Y. Yoon, S. Kim and E. Oh, Multifunctional drug delivery system using starch-alginate beads for controlled release, Biol. Pharm. Bull. 28 (2005) 394-397.

4. C. K. Kim and E. J. Lee, The controlled release of blue dextran from alginate beads, Int. J. Pharm, 79 (1992) 11-19; DOI: 10.1016/0378-5173(92)90088-J.

5. P. F. Almeida and A. J. Almeida, Cross-linked alginate beads: a new matrix for controlled release of pindolol, J. Control. Rel. 97 (2004) 431-439; DOI: 10.1016/j.jconrel.2004.03.015.

6. I. Nuran, Controlled release of insecticide carbaryl from sodium alginate, sodium alginate/gelatin, and sodium alginate/sodium carboxymethyl cellulose blend beads crosslinked with glutaraldehyde, J. Appl. Polym. Sci. 99 (2006) 1310-1319; DOI: 10.1002/app.22012.

7. L. H. Sperling, Interpenetrating Polymer Networks and Related Materials, Plenum Press, New York 1981.

8. E. A. Shipton, Tramadol - present and future, Anaesth. Int. Care 28 (2000) 363-374.

9. B. Singh, S. K. Chakkal and N. Ahuja, Formulation and optimization of controlled release mucoadhesive tablets of atenolol using response surface methodology, AAPS PharmSciTech 7 (2006) E1-E10; DOI: $10.1208 / \mathrm{pt070103.}$

10. B. Singh, R. Kumar and N. Ahuja, Optimizing drug delivery systems using systematic "design of experiments". Part I: fundamental aspects, Crit. Rev. Ther. Drug Carrier Syst. 22 (2005) 27-105; DOI: 10.1615/CritRevTherDrugCarrierSyst.v22.i1.

11. N. A. Peppas and N. M. Franson, The swelling interface number as a criterion for prediction of diffusional solute release mechanisms in swellable polymers, J. Pol. Sci. Pol. Phys. Ed. 21 (1983) 983-987; DOI: 10.1002/pol.1983.180210614.

12. P. He, S. S. Davis and L. Illum, In vitro evaluation of mucoadhesive properties of chitosan microspheres, Int. J. Pharm. 166 (1998) 75-88; DOI: 10.1016/S0378-5173(98)00027-1.

13. United States Pharmacopeia 31, National Formulary 26, The United States Pharmacopeial Convention, Rockville 2008, 267-274.

14. R. W. Korsmeyer, R. Gurny, E. M. Doelker, P. Buri and N. A. Peppas, Mechanism of solute release from porous hydrophilic matrices, Int. J. Pharm. 15 (1983) 25-35; DOI: 10.1016/0378-5173 (83)90064-9. 
P. Kumar and I. Singh: Formulation and characterization of tramadol-loaded IPN microgels of alginate and gelatin: Optimization using response surface methodology, Acta Pharm. 60 (2010) 295-310.

15. T. Higuchi, Mechanism of sustained action medication: Theoretical analysis of rate of release of solid drugs dispersed in solid matrices, J. Pharm. Sci. 52 (1963) 1145-1149; DOI: 10.1002/jps. 2600521210.

16. K. Wang and Z. He, Alginate-konjac glucomannan-chitosan beads as controlled release matrix, Int. J. Pharm. 244 (2002) 117-126; DOI: 10.1016/S0378-5173(02)00324-1.

17. T. Caykara, G. Sengül and G. Birlik, Preparation and swelling properties of temperature-sensitive semi-interpenetrating polymer networks composed of poly[( $N$-tert-butylacrylamide)-co-acrylamide] and hydroxypropyl cellulose, Macromol. Mater. Eng. 291 (2006) 1044-1051; DOI: 10. 1002/ mame.200600063.

18. X. Zhao, K. Kato, Y. Fukumoto and K. Nakamae, Synthesis of bioadhesive hydrogels from chitin derivatives, Int. J. Adhes. Adhes. 21 (2001) 227-232; DOI: 10.1016/S0143-7496(01)00003-3.

19. A. Bernkop-Schnürch, Chitosan and its derivatives: potential excipients for peroral peptide delivery systems, Int. J. Pharm. 194 (2000) 1-13; DOI: 10.1016/S0378-5173(99)00365-8.

\section{Izrada i karakterizacija IPN alginatnih i želatinskih mikrogelova s tramadolom: Optimiranje pomoću metode odzivnih površina}

PRADEEP KUMAR i INDERBIR SINGH

Interpenetrirajući umreženi polimerni (IPN) alginatno-želatinski (AG) mikrogelovi (MG) tramadola pripravljeni su metodom umrežavanja koristeći glutaraldehid kao sredstvo za umrežavanje. Pripravci su optimirani pomoću odzivnih površina. Kompozitini dizajn s dva faktora na tri nivoa upotrijebljen je za procjenu kritičnih formulacijskih varijabli: praćen je utjecaj količine želatine $\left(X_{1}\right)$ i glutaraldehida $\left(X_{2}\right)$ na prosječnu veličinu čestica, sposobnost kapsuliranja, koeficijent difuzije $(D)$, količinu adsorbiranog mucina po jedinici mase $\left(Q_{\mathrm{e}}\right)$ i vrijeme potrebno za oslobađanje $50 \%$ lijeka $\left(t_{50}\right)$. Dobiveni su mikrogelovi prosječne veličine čestica od 44,31 do $102,41 \mu \mathrm{m}$, a maksimalno postignuto vezanje lijeka bilo je 86,5 \%. Mikrogelovi su karakterizirani FT-IR spektroskopijom i diferencijalnom pretražnom kalorimetrijom (DSC). Ravnotežne i dinamičke studije bubrenja provedene su u fosfatnom puferu $\mathrm{pH} 7,4$. Koeficijenti difuzije i eksponenti za transport vode određeni su pomoću empirijske jednadžbe. Mukoadhezivna svojstva MGs evaluirana su $\mathrm{u}$ vodenoj otopini mjerenjem adsorpcije mucina na mikrogelove. Konstruirane su adsorpcijske izoterme i uspoređene s Freudlichovim i Langmuirovim jednadžbama. Pokusi in vitro pokazuju da oslobađanje ljekovite tvari ovisi o stupnju umreženja i količini želatine upotrijebljene u pripravi IPN. Vrijednosti oslobađanja uvrštene su u jednadžbu zakona potencije i u Higuchijev model kako bi se izračunali razni parametri prijenosa lijeka; $n$ vrijednosti bile su između 0,4055 i 0,5754, što ukazuje na to da oslobađanje varira od Fickovog do kvazi-Fickovog, ovisno o sastavu pripravka.

Ključne riječi: natrijev alginat, želatina, mikrogel, IPN, difuzija, adsorpcija na sluznici

Chitkara College of Pharmacy, Chandigarh-Patiala National Highway, Rajpura-140401, Patiala, Punjab, India 